\title{
Percutaneous Mitral Valve Repair
}

National Cancer Institute

\section{Source}

National Cancer Institute. Percutaneous Mitral Valve Repair. NCI Thesaurus. Code C100003.

Invasive procedure through a puncture in the skin, performed for the purpose of reducing regurgitation of the mitral valve. (ACC) 